\title{
A DEBRIS FLOW DEPOSIT IN MAMMOTH CAVE: FIELD CHARACTERIZATION
}

\author{
Rachel Bosch ${ }^{1 . C}$, Dylan Ward ${ }^{1}$, Aaron Bird², Dan Sturmer ${ }^{1}$, and Rick Olson ${ }^{3}$
}

\section{Abstract}

This work presents an analysis of a debris flow deposit below Earth's surface in the Mammoth Cave System in Kentucky, USA, and is the first study to characterize an in-cave debris flow to this level of detail. The deposit, named Mt. Ararat by cavers, has a maximum thickness of $7 \mathrm{~m}$, a head-to-tail length of $75 \mathrm{~m}$, and a total volume of about $3400 \mathrm{~m}^{3}$, as determined by terrestrial LiDAR and electrical resistivity surveys. The deposit is chaotic, angular, matrix-supported, and roughly inversely graded, with grain sizes, quantified through various grain-size distribution measuring techniques, ranging from clay through boulders larger than $1 \mathrm{~m}$. The clasts are predominantly Mississippian Big Clifty sandstone, which is allochthonous in this part of the cave. The angularity of the blocks in the deposit indicate that they had not experienced significant erosion; and therefore, are determined to have been transported only a relatively short distance over a short time. The deposit profile is compound in appearance with two heads. We thus interpret this as a debris flow deposit resulting from two distinct flow events, and present a chronology of events leading to the present-day Mt. Ararat in Mammoth Cave. The findings of this work will inform further studies of karst-related erosional events, sediment transport, and deposition at different scales in karst aquifers, as well as the ways in which surface and subsurface processes interact to contribute to karst landscape evolution.

\section{INTRODUCTION}

While karst landscapes vary widely, those with extensive subterranean drainage systems are often associated with unconfined carbonate sequences overlain and underlain by more chemically-resistant beds. As erosion progresses in these landscapes, clastic sediments from the resistant layers are washed into and through subterranean conduits. Significant amounts of clastic sediment must be transported through cave conduits to keep the passages open. Like surface sediment deposits, cave sediments are classified according to grain size, sorting, and sedimentary structures. These deposits can then be interpreted in terms of the conditions of their transport and deposition.

In this study, we focus on a diamictic deposit of sandstone boulders deep under the Central Kentucky Karst landscape in Mammoth Cave. In 1971, John Wilcox noted these boulders on his map as "sandstone breakdown" (Wilcox, 1971). The deposit_later named "Mt. Ararat" by cavers_prompted further scrutiny in 2016, when Art and Peg Palmer began to investigate why this much sandstone was located so far into the cave, where the smooth, gently rounded limestone ceiling meant it could not in fact be a breakdown pile (Palmer et al., 2019). They hypothesized that it was the result of transport during a large flood.

\section{DIAMICTON FACIES SEDIMENTATION}

In discussion of the sedimentary facies concept as applied to siliciclastic sedimentation in caves, Bosch and White $(2004 ; 2018)$ defined a massive, matrix-supported clay to boulder facies that is chaotic, unsorted, and unbedded with the interpretation of diamicton cave deposit as "the result of debris flows where materials of all particle sizes are taken into suspension and flow down high gradient passages" (Bosch and White, 2018).

Terrestrial (Takahashi, 1981; Pierson, 1986; Hungr, 1995) and submarine (Prior et al., 1984) debris flow deposits resulting from single-flow events were reported in field studies as simple profiles beginning with relatively fine material at the upstream "tail," increasing in thickness

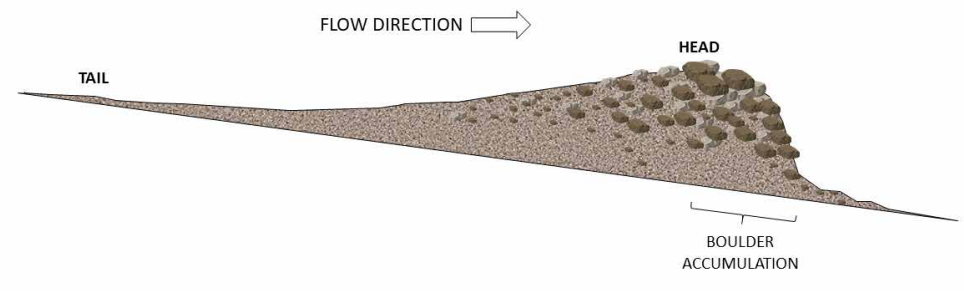

Figure 1. Schematic drawing of a single-surge debris flow in profile with major geometry names labeled (after Pierson, 1986). downstream and coarsening toward the steep front, or "head," with a boulder accumulation at the head. The geometry of debris flows was described in detail by Pierson (1986; Fig. 1) based upon his observations of deposits resulting from channelized debris flows following the 1980 eruption of Mount St. Helens, Washington, USA.

Debris flows and their resulting diamicton deposits have been observed and described in caves throughout the world. Many descriptions in the litera-

\footnotetext{
1Department of Geology, University of Cincinnati, Cincinnati, Ohio 45221-0013 USA Current affiliation: Department of Physics, Geology, and Engineering Technology, Northern Kentucky University, Nunn Drive, SC 114, Highland Heights, KY 41099

${ }^{2}$ Siemens Digital Industries Software, 2000 Eastman Dr, Milford, Ohio 45150 USA

${ }^{3}$ Division of Science and Resource Management, Mammoth Cave National Park, Mammoth Cave, Kentucky 42259-0007 USA

cCorresponding author, boschr1@nku.edu
} 
ture were written to provide detailed stratigraphy as a necessary context for anthropological or archaeological studies because catastrophic debris flows that came to be deposited in caves were also ideal for entrapment and preservation of bones from the Pliocene through the Holocene. In El Sidrón Cave in Asturia, Spain (Santamaría et al., 2010), there is a deposit described as a "Unit of poorly sorted gravels, sands and mud" which has been interpreted as "fluvial-karstic materials [that] originated from a high energy event and [were] clearly erosive in nature." Similar deposits were investigated as an archaeological complex in Scladina Cave in Belgium (Abrams et al., 2014), interpreted as having been "dominated by solifluction and debris flow." Multiple debris flows hosting archaeological materials were documented in the Great Cave of Niah in Sarawak, northern Borneo (Gilbertson et al., 2005) one of these flows being a diamicton of guano, clay clasts, and limestone boulders with a lobate planform, and another described as "diamicton composed of pink silt-sized material with variably sized white inclusions, interpreted as having resulted from a mudflow." An archaeological site particularly worthy of note, the Malapa Site located in the Cradle of Humankind World Heritage Site in South Africa (Dirks et al., 2010), contains debris flow deposits with "abundant, well-preserved macro- and micromammal fossils." This deposit is a "poorly sorted, coarse-grained sandstone . . . cemented by blocky sparite," that "contains allochthonous material (chert, shale and feldspar grains, bone fragments) mixed with cave-derived sediment, suggesting deposition as a single debris flow. .."

Other studies have been written from an exclusively geological or geomorphological perspective. Gillieson pioneered studies of siliciclastic sediments in caves with his 1986 study of Selminum Tem in the Highlands of Papua New Guinea. In that work he noted that, "Two diamictons are present in the main passage of Selminum Tem. One attains a maximum depth of $5 \mathrm{~m}$ in Coprates Canyon, a $30 \mathrm{~m}$ high vadose canyon. . . The diamicton is a silty fine sandy pebble gravel which is matrix supported and unstratified." The Butler Cave-Sinking Creek System in Virginia, USA (Chess et al., 2010) contains extensive siliciclastic deposits, the "most remarkable" of which "are the diamicton facies. . . These are unsorted and unstratified mixtures of sand, pebbles, and cobbles. These seem to have infilled all of the side caves on the western side of the system. . . Diamicton facies implies a debris flow. . ." In a study of a modern event, Van Gundy and White (2009) detailed a volume of material that they estimated at $1800 \mathrm{~m}^{3}$ (from before and after measurements of the sediment source area) that was transported completely into, through, and out of Mystic Cave in West Virginia, USA, during the "1985 Potomac Valley flood." The observed sediments that were discovered wedged into crevices in the cave after the storm contained a broad "range of particle sizes with a significant fraction of cobble-sized colluvium." When they divided mean-known discharges during the storm event by the cross-sectional area of smaller conduits in Mystic Cave, they arrived at an estimated water velocity of 5-9 m/s required to move that volume of water through some portions of the cave.

\section{FIELD SETTING}

Big Avenue, Noah's Way, and Fossil Avenue are adjoining cave passages formed at approximately the same elevation in the Joppa member of the Ste. Genevieve limestone in Mammoth Cave, Mammoth Cave National Park, Kentucky, USA. At the junction of Big Avenue and Noah's Way, is an unconsolidated deposit of rocks named Mt. Ararat. It is about 12-15 m wide with a maximum relief of $7 \mathrm{~m}$ and a $75 \mathrm{~m}$ long tail that extends into Noah's Way. The grains in this deposit consist of a buff-colored fine- to medium-grained quartz sandstone consistent with descriptions of the Big Clifty sandstone member of the Mississippian Golconda formation, which is stratigraphically about $60 \mathrm{~m}$ above the Joppa limestone (Fig. 2). Additionally, the ceiling above the pile is smooth and rounded (Fig. 3). From this evidence, Palmer et al. (2019) inferred that there had been no stoping, that is, the blocks did not break down from the ceiling. Therefore, the rocks making up this deposit were concluded to be allochthonous.

Four discrete levels are observed consistently throughout the over four-hundred miles of mapped passage in the Mammoth Cave System and have been labeled A through D by Palmer (1989) with A at about $200 \mathrm{~m}$ ASL, B at 177-186 $\mathrm{m} \mathrm{ASL}, \mathrm{C}$ at 166-167 m ASL, and D at 151-158 m ASL. The passages associated with the Mt. Ararat deposit correlate in elevation with other level C passages. Granger at al. (2001) performed cosmogenic radionuclide burial dating using ${ }^{26} \mathrm{Al}$ and ${ }^{10} \mathrm{Be}$ to sequence the events that resulted in these levels. During that study, they dated quartz gravels (originally from the Pennsylvanian Caseyville conglomerate) sampled from Fossil Avenue (elevation $167 \mathrm{~m} \mathrm{ASL}$ ), approximately $400 \mathrm{~m}$ from its junction with Big Avenue (elevation $166 \mathrm{~m} \mathrm{ASL}$ ), at $1.21 \pm 0.09 \mathrm{Ma}$. Additionally, detailed observations of Mt. Ararat have revealed no Caseyville gravels, which was interpreted as the timing of fluvial deposition of these gravels; and therefore, the time at which this passage was last active as a cave stream flow route at base level. Beginning from this approximate timing of younger than $1.21 \mathrm{Ma}$, we used sedimentological analyses, terrestrial LiDAR, and geophysical data to deduce a sequence of events contributing to deposition of Mt. Ararat.

\section{METHODS}

\section{FIELD OBSERVATIONS}

Observations were made to characterize the sediment deposit named Mt. Ararat in Mammoth Cave, cave passages containing that deposit, and the geomorphology of Doyle Valley on the surface above. (Although "Doyel" is the spelling 


\section{Mammoth Cave Debris Flow Deposits}

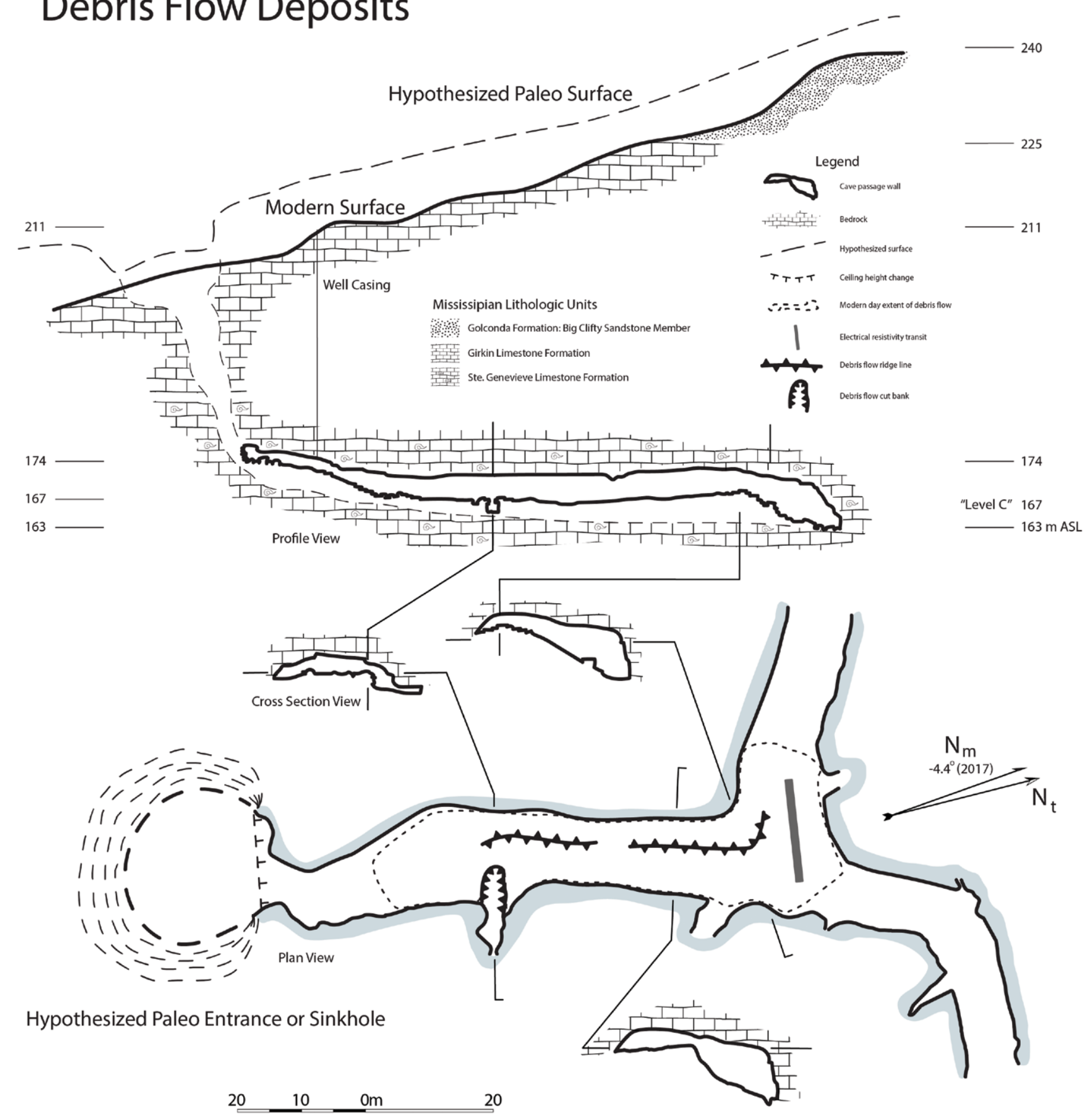

Figure 2. Study area: Mt. Ararat deposit in Noah's Way, Mammoth Cave System, Mammoth Cave National Park, Kentucky, USA. Cave cartography by Bird. (Location topographic map, USGS, 1972; Haynes, 1964; Cave Research Foundation 2010a, 2010b, 2012; Wilcox, 1971).

found on USGS maps (Haynes, 1964; USGS, 1972) and in USNPS publications (2018), Mammoth Cave area historians concur that "Doyle" is the preferred local spelling (Palmer, pers. Comm., 2019)). Field survey books and maps provided by the Cave Research Foundation (1971, 2010a, 2010b, 2012) were used as references for in-cave fieldwork and for cartography of the study area (Fig. 2). Surface field work drew upon the same Cave Research Foundation (CRF) cave data, 

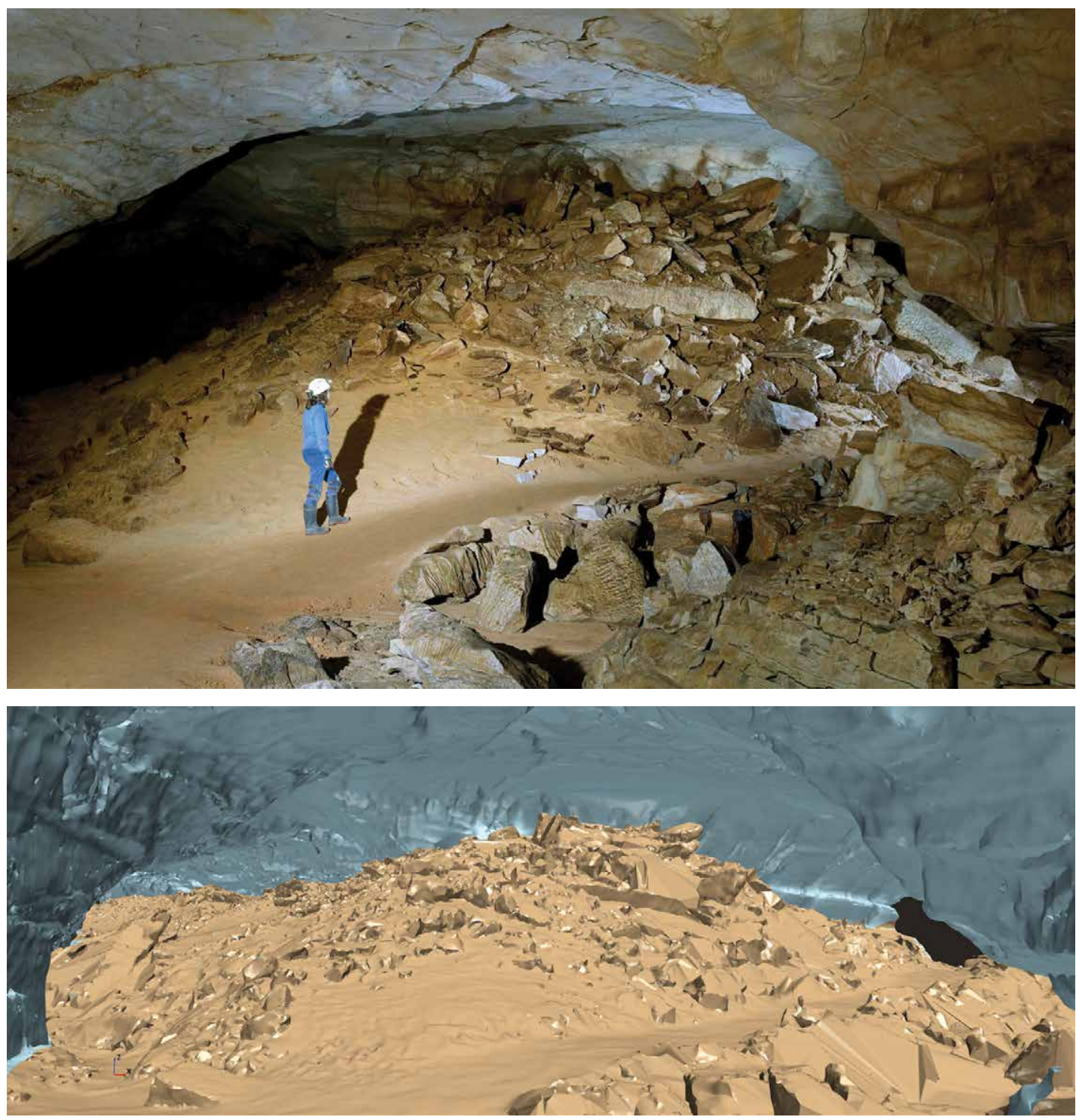

Figure 3. Head of Mt. Ararat as seen from Big Avenue, standing to the northeast of the deposit. A) Photo used with permission of the photographer, Arthur N. Palmer. B) LiDAR scan of Mt. Ararat with portions of Noah's Way and Big Avenue. topographic and geologic maps (Haynes, 1964; USGS, 1972), and the global positioning system app for iOS, GPS Kit (2017). We defined the volume of material in Mt. Ararat using terrestrial LiDAR for the aerially exposed surface and an electrical resistivity survey to estimate the obscured portion. The facies analysis and interpretations of clastic sediment deposits in the cave were made according to the classification scheme of Bosch and White (2018).

\section{Terrestrial LiDAR}

To characterize the outer surface geometry of Mt. Ararat, Tate Jones led a surveying team from $\mathrm{KCl}$ Technologies to perform LiDAR scans of the deposit and its immediately surrounding cave passages. They used a RIEGL VZ-400i to perform four three-dimensional terrestrial LiDAR scans in the cave. The point clouds from these scans were merged to result in a high-resolution stereolithography file of the surface of Mt. Ararat (Fig. 3B). The resulting mesh comprised over 5.5 million triangles, each about $0.06 \mathrm{~m}$ on a side, encompassing $240 \mathrm{~m}$ of cave passage length with ceilings approximately $7 \mathrm{~m}$ high and passages widths of about $10 \mathrm{~m}$ throughout their length. This level of resolution was observed to accurately capture details of the caves passages and individual rocks when compared with photographic evidence and cartographic survey and therefore also realistically reconstructed the shape and structure of Mt. Ararat.

\section{Sedimentology}

To determine grain-size distribution for the entire Mt. Ararat deposit, analysis was needed at multiple scales. At the highest precision and finest scale was the fine-grained matrix of the deposit. Mt. Ararat appears to have been partially eroded on its eastern (right-lateral) side by a younger, high-gradient stream, exposing a cross-section that displays a lack of sorting and sedimentary structure in the deposit, with grain sizes ranging from clays to boulders on the order of $1 \mathrm{~m}$ on a side (Fig. 4). From this exposed face, we collected three sediment samples: MAXC1, MAXC2, and MAXC3. Dry-sieving of these samples was performed using methods outlined in ASTM (Smith, 2014) using stacked sieves on a mechanical shaker with mesh sizes of $8 \mathrm{~mm}, 4, \mathrm{~mm}, 2 \mathrm{~mm}, 1 \mathrm{~mm}, 500 \mu \mathrm{m}, 250 \mu \mathrm{m}, 125 \mu \mathrm{m}, 63 \mu \mathrm{m}$, and $38 \mu \mathrm{m}$.

At the next scale larger in this deposit, a grid-square counting technique was implemented to assess grain-size analysis on the entire cross-section of the exposed face (Fig. 5) (Kellerhals et al., 1975; Ortiz et al., 1975). Each $10 \mathrm{~cm}$ by 10 $\mathrm{cm}$ grid box was labeled with either the diameter of the largest clast in that square, or if there was not a significant indi- 


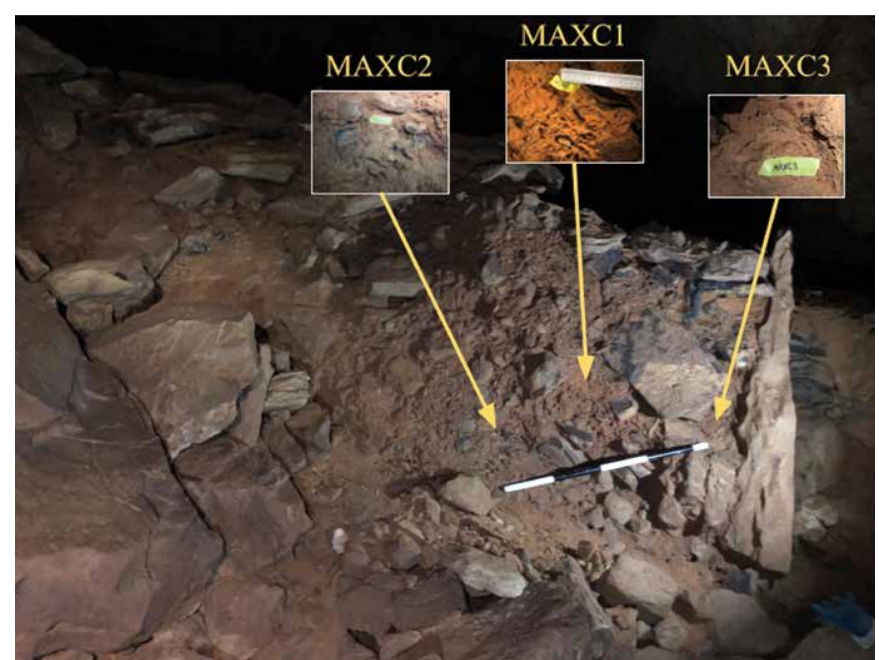

Figure 4. Exposed cross-section of Mt. Ararat. Poorly sorted, matrix-supported clastic sediments with a very wide grain-size distribution. Note the large boulders near the top of the deposit. Interpretation is a diamicton deposit resulting from a catastrophic debris-flow event. Matrix sampling locations are shown inset. Scale bar has $20-\mathrm{cm}$-long alternating white and black segments. Photo by Bosch.

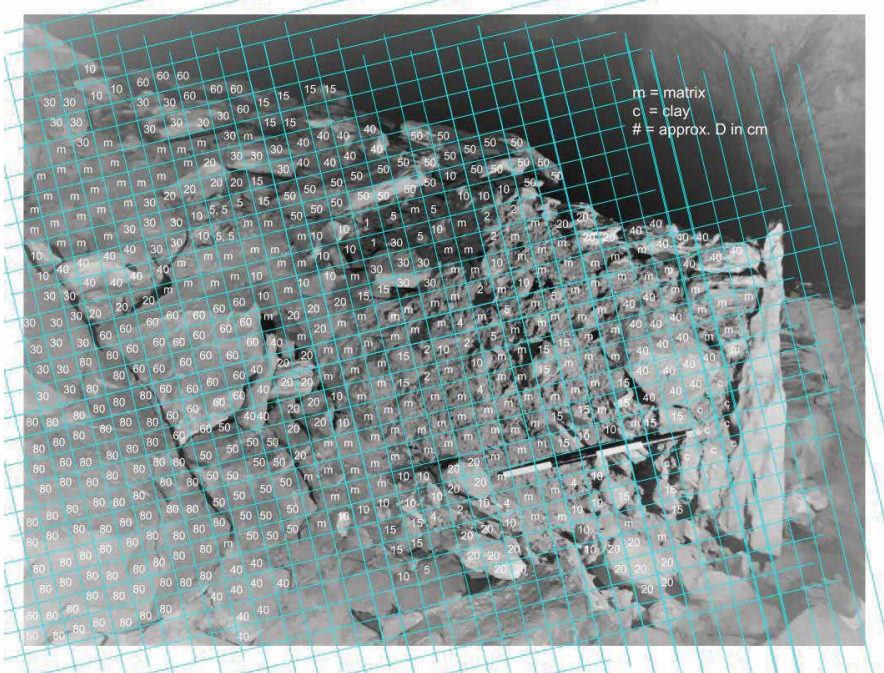

Figure 5. Grain-size analysis for exposed cross-section of Mt. Ararat. Grid-squares for grain-size distribution analysis.

vidual clast visible, the grid square was labeled $m$ for matrix, or in the case of the few squares we identified in the field as clay-dominated, c for clay. Boxes with clasts comprised 70 $\%$ of the exposed-section surface area, while matrix- and clay-dominated boxes accounted for $30 \%$ of the section. To construct the grain-size-distribution curve, the cumulative percentage results from sieving the matrix material were multiplied by 0.3 and the whole-clast grid-counting results were plotted relative to the entire gridded section (Fig. 6).

\section{Electrical resistivity}

Near-surface geophysics was used to approximate the subsurface stratigraphy in Big Avenue near the junction with Noah's Way (Fig. 2). Since Mt. Ararat's material covers the paleo bedrock floor of the passage, we used electrical resistivity tomography to constrain the thickness of the deposit. We used an IRIS Syscal Kid Switch24 to perform a Wenner Vertical Electrical Survey (VES) along the trail. A Wenner VES assesses the vertical resistivity profile below one point by acquiring readings on progressively longer arrays, with increased array lengths sampling deeper stratigraphy (Burger et al., 2006). We set up arrays with intervals of 0.5 $\mathrm{m}, 1 \mathrm{~m}, 1.5 \mathrm{~m}, 2 \mathrm{~m}, 3 \mathrm{~m}, 4 \mathrm{~m}$, and $4.5 \mathrm{~m}$. The resistivity readings from each of these arrays were used to model the vertical profile using the program ipi2WIN (Bobachev, 2002). This modeled near-surface stratigraphy was used to help constrain the three-dimensional geometry of the deposit.

\section{Morphological analyses}

A longitudinal profile and seven cross sections were measured using the Profile Tool plugin (Jurgiel, et al., 2020) in QGIS (QGIS.org, 2020) on a digital elevation model of Mt. Ararat built in CloudCompare (2020) using the point cloud obtained from the terrestrial LiDAR survey (Fig. 8). The volume of the deposit was constrained by the LiDAR-scanned topography and the position of the underlying passage floor inferred from the electrical resistivity near-surface stratigraphy model. Using the multiphysics modeling software, STAR-CCM+ (Siemens, 2020), the stereolithography mesh was imported as a geometry part. All holes in the model were then closed using the surface repair tool in STAR$\mathrm{CCM}+$. The bedrock passage floor was modeled as a plane coincident with the bedrock floor location inferred from electrical resistivity. Where the flat floor did not intersect the LiDAR surface, planes were introduced to model bedrock passage wall obscured by Mt. Ararat where the deposit contacts the western wall along Noah's Way and the southern wall of Big Avenue in the inside of the bend. Using this combination of three plane surface and the LiDAR-derived surface, a geometric model of the Mt. Ararat deposit was isolated.

\section{RESULTS}

\section{Surface topography relative to debris flow deposit}

On the cave map by John Wilcox (1971), about $75 \mathrm{~m}$ beyond the junction with Big Avenue, in Noah's Way, there is a note written at survey station V-11: "bore hole directly above." Upon visual inspection in the cave, we observed a small copper pipe protruding a few centimeters from the passage ceiling. Further upstream from this, the passage has limestone breakdown and travertine deposits and becomes impassible to humans. The origin and possible motivation for installing this pipe before Mammoth Cave was administered by the National Park Service is unknown. However, it provided an opportunity to robustly tie cave observations to surface observations. Using that cave map in conjunction 
Mt. Ararat grain size distribution

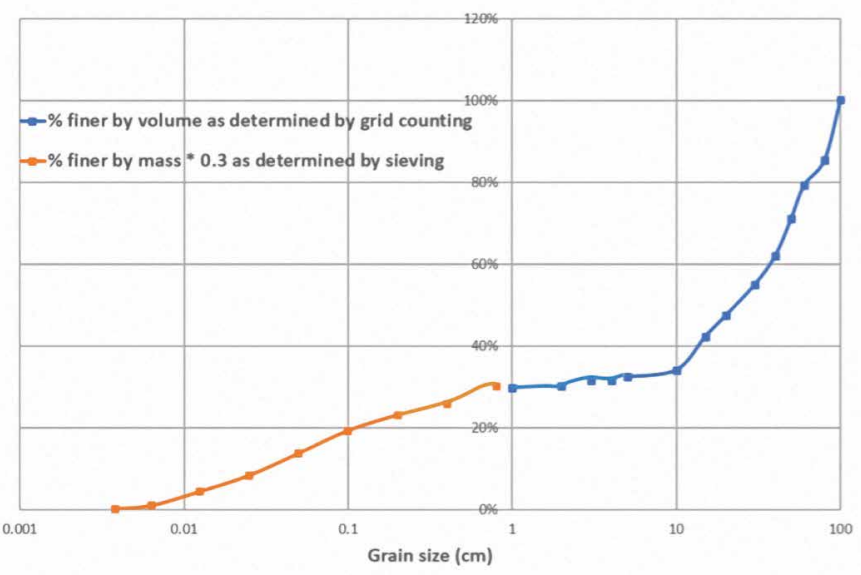

Figure 6. Grain-size distribution curve for exposed cross-section of Mt. Ararat. Finer grained matrix mass percentage determined by sieving. Coarser grained clasts volume percentage determined by grid-counting. Since this material is concluded to have derived from the Big Clifty sandstone, it is of uniform density, and these two approaches are therefore directly comparable.

with the app GPS Kit, the surface end of the "bore hole" was found at an elevation of $210 \mathrm{~m} \mathrm{ASL}$ on the north side of Doyle Valley (Fig. 2).

The contact between Girkin Limestone Formation and Big Clifty Sandstone Member of the Golconda Formation is at about $225 \mathrm{~m}, 15 \mathrm{~m}$ above the borehole. At this elevation the landscape slope becomes much gentler. These are the plateau-like Jim Lee Ridge and Joppa Ridge to the north-northeast and south-southwest of Doyle Valley, respectively. Throughout Mammoth Cave National Park, there are ponds intermittently perched on the Big Clifty sandstone on the ridges (Studinski and Grubbs, 2007).

A sinkhole in the floor of Doyle Valley was found at about $140 \mathrm{~m}$ horizontal distance south-southwest from the bore hole and at an elevation of $200 \mathrm{~m}$; it was dry when we completed our surface reconnaissance work and is indicative of the closest modern place for water to enter the Noah's Way area of Mammoth Cave. An entrance point for the material that became Mt. Ararat may have looked somewhat like this but at 2-7 $\mathrm{m}$ higher in elevation (Fig. 2) due to the 2-7 m/Ma erosion rate presented by Granger et al. (2001). If we add $2 \mathrm{~m}$ to account for the minimum estimated erosion, the shortest travel distance from the nearest modern exposure of the contact to the upstream end of Noah's Way is the resultant of the vertical offset of $62 \mathrm{~m}$ with the horizontal distance of about $200 \mathrm{~m}$, or about $210 \mathrm{~m}$ of straight-line travel. This estimate is, of course a minimum, since transport would not likely be in a straight line.

\section{Sedimentology}

Table 1. Grain-size distribution of Mt. Ararat matrix material from sieve analysis.

\begin{tabular}{|c|c|c|c|c|c|}
\hline \multicolumn{2}{|c|}{$\begin{array}{c}\text { Cumulative sediment } \\
\text { mass }(\mathrm{g})\end{array}$} & \multicolumn{2}{|c|}{$\begin{array}{l}\text { Grain size } \\
\qquad(\mathrm{mm})\end{array}$} & \multicolumn{2}{|c|}{$\begin{array}{l}\text { Percentage finer } \\
\text { by weight (\%) }\end{array}$} \\
\hline MAXC1 & MAXC2 & MAXC1 & MAXC2 & MAXC1 & MAXC2 \\
\hline 48.35 & 67.55 & 8 & 8 & 100 & 100 \\
\hline 48.35 & 48.8 & 4 & 4 & 100 & 72 \\
\hline 46.75 & 38.4 & 2 & 2 & 97 & 57 \\
\hline 38.85 & 32.1 & 1 & 1 & 80 & 48 \\
\hline 28.35 & 21.8 & 0.5 & 0.5 & 59 & 32 \\
\hline 17.65 & 12.5 & 0.25 & 0.25 & 37 & 19 \\
\hline 8.35 & 7.7 & 0.125 & 0.125 & 17 & 11 \\
\hline 1.25 & 2.1 & 0.063 & 0.063 & 3 & 3 \\
\hline 0.2 & 0.35 & 0.038 & 0.038 & 0 & 1 \\
\hline
\end{tabular}

Table 2. Raw data results of electrical resistivity survey.

\begin{tabular}{cc}
$\begin{array}{c}\text { Depth below center } \\
\text { of VES Array }(\mathbf{m})\end{array}$ & $\begin{array}{c}\text { Measured resistivity } \\
(\mathbf{\Omega} \cdot \mathbf{m})\end{array}$ \\
\hline 0.5 & 175.98 \\
1 & 651.29 \\
1.5 & 1532.35 \\
2 & 6059.78 \\
3 & 2483.17 \\
4 & 1961.21 \\
4.5 & 1003.91 \\
\hline
\end{tabular}

Grain-size distributions for samples of the deposit matrix as determined by sieving MAXC1 and MAXC2 were similar to one another (Table 1). The third matrix sample, MAXC3, was nearly 100 $\%$ clay. These were combined to create a grainsize distribution for the matrix of the cross-section exposed by erosion with a minimum grain size of $0.0038 \mathrm{~cm}$, a maximum of $0.8 \mathrm{~cm}$, and a D50 of about $0.05 \mathrm{~cm}$. When plotted as $30 \%$ of the total grain-size distribution, with the grid-counting results contributing the other $70 \%$, the maximum grain size was then $100 \mathrm{~cm}$ and the D50 for the entire cross-section grain-size distribution was about $20 \mathrm{~cm}$ (Fig. 6).

\section{Obscured stratigraphy}

Measurements recorded during the electrical resistivity tomography (ERT) survey (Table 2) represent the resistivity encountered by an electrical signal as it traveled through multiple stratigraphic layers, each with a different resistivity. The raw data then shows 


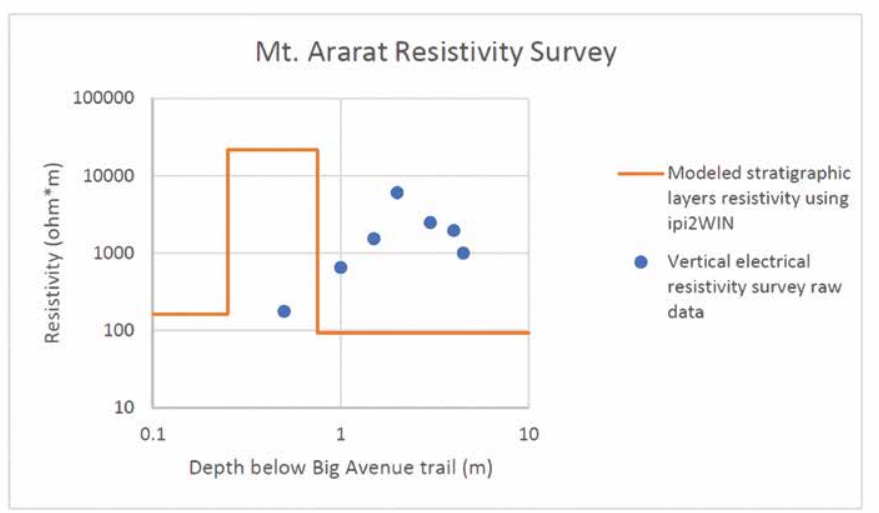

Figure 7. Raw electrical resistivity signal responses and modeled electrical resistivity strata. Data modeling indicates the trail depth below the center of the resistivity array at $0.25 \mathrm{~m}$ (horizon $\mathrm{A}$ ), debris flow deposits from $0.25 \mathrm{~m}$ to $0.75 \mathrm{~m}$ in depth (horizon $\mathrm{B}$ ), and below $0.75 \mathrm{~m}$ as bedrock with vugs and fractures (horizon $\mathrm{C}$ ).
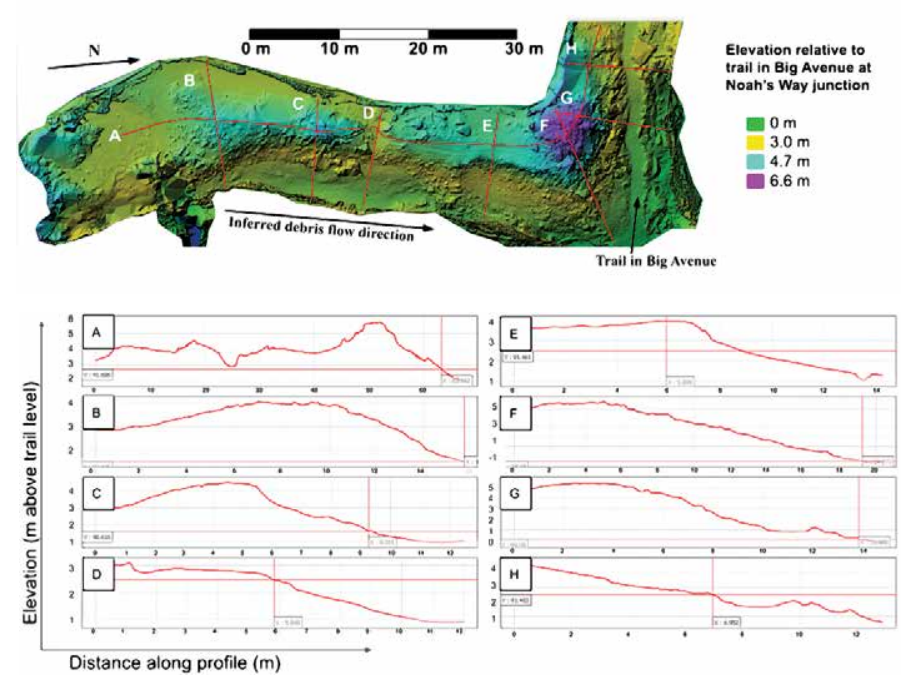

Figure 8. Digital elevation model of Mt. Ararat along the spine, A, and at seven cross-sections, $\mathrm{B}$ through $\mathrm{H}$. (Fig. 8A). About $20 \mathrm{~m}$ upstream from that secondary peak, the tail of the deposit tapers off and is obscured by limestone breakdown. Along the western wall of Noah's Way, the deposit is in continuous contact with the wall. The coarsest grain sizes in Mt. Ararat, found at the taller peak, are boulders of greater than $1 \mathrm{~m}$ in diameter, with the second highest concentration of large grains located at the second peak.

Two areas of Mt. Ararat show evidence of surface modification postdating deposition. Along the eastern wall of Noah's Way, for about $40 \mathrm{~m}$, the side of Mt. Ararat has the appearance of a cutbank at the angle of repose for silt, rising to the west from a small feature that appears to be an abandoned channel up toward the crest of the deposit (Fig. 8E). The stream, when it occupied that channel, would have drained from Noah's Way out to Big Avenue. Upstream from the large peak, about $50 \mathrm{~m}$ up Noah's Way, there is a side passage leading away to the east. At the entrance to this deposit, Mt. Ararat has been partially eroded through its entire vertical extent to reveal a cross-section of the deposit (Fig.4), and $10 \mathrm{~m}$ further down that side passage is a small, hydrologically active stream.

From the tall peak at the junction of Noah's Way and Big Avenue, the deposit makes a sharp turn to the west, into Big Avenue, with its left-lateral side remaining in contact with the cave passage wall (Figs. 8G, 8H). Slopes around that peak area of Mt. Ararat vary due to the wide range of grain sizes but are roughly at the angle of repose and continue under the human-built trail in Big Avenue toward the cave passage floor.

We used the LiDAR point cloud and resistivity depth profile to evaluate the volume of material represented by the deposit. The resistivity results indicated that the bedrock floor near the junction of Big Ave and Noah's Way lies 0.75 $\mathrm{m}$ below the trail at the center of the array (Fig 9). At the southeast corner of Noah's Way, bedrock is exposed where a 


\section{Mt. Ararat Debris Flow Deposit}

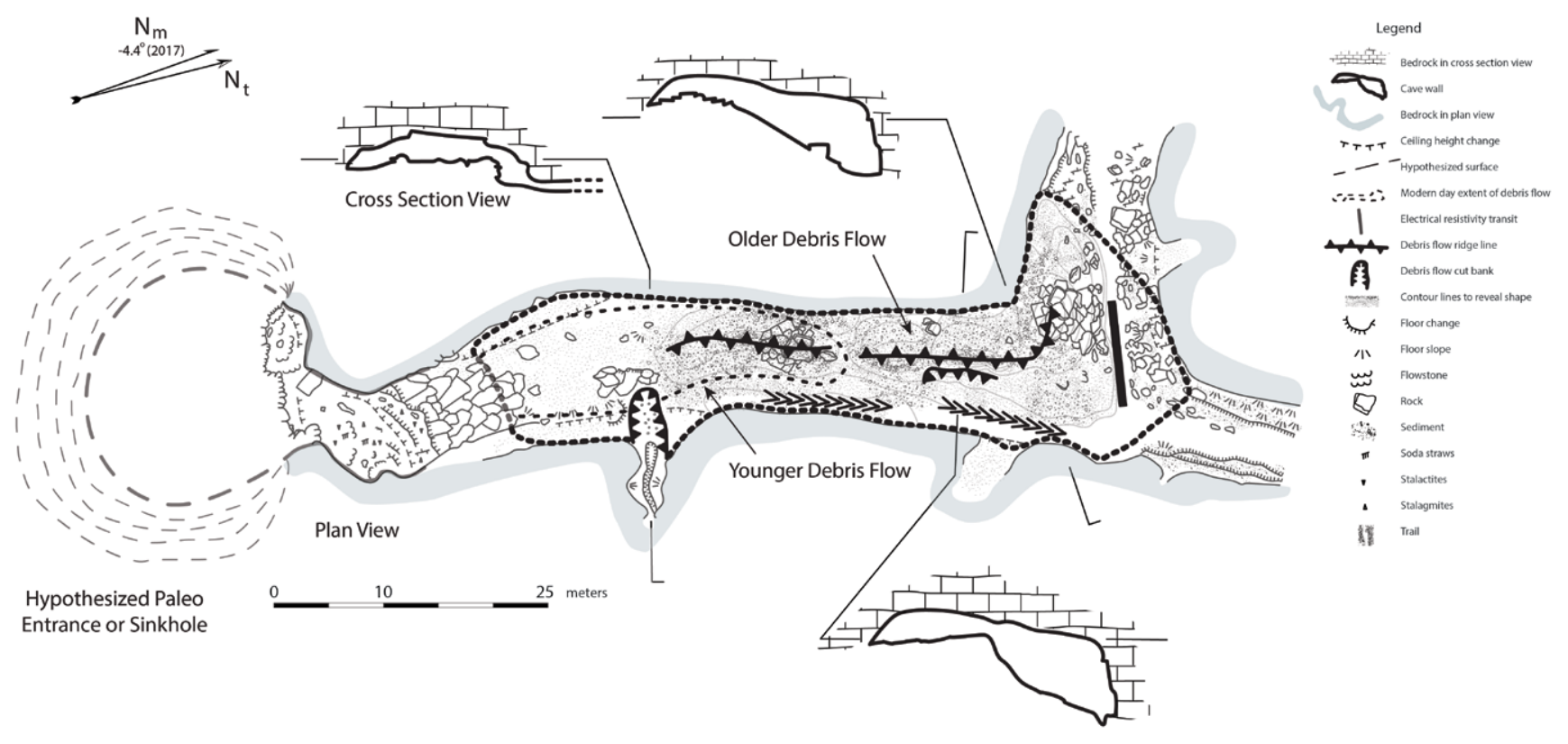

Figure 9. Geomorphological map of Mt. Ararat with sequence of depositional and erosion events as follows: 1) deposition of primary, large, debris flow; 2 or 3) fluvial erosion of primary, and perhaps also secondary, debris flow(s) along eastern wall channel; 3 or 2 ) deposition of secondary, smaller, debris flow; head of small debris flow marked by grain-size transition from large-gravel- to sand-dominated in the downstream direction; and 4) erosion of primary and secondary debris flow into eastern side passage. Map symbols consistent with Gustavsson et al. (2006).

smaller passage opens through the floor, and its position qualitatively supports the assumption of a roughly constant bedrock floor level along the length of Noah's Way. The exact relationship between this bedrock exposure and the Mt. Ararat deposit is obscured by a later-stage breakdown jumble. Neither the resistivity profile, nor observations of scattered alluvial cave deposits in Big Avenue and Fossil Avenue, support the premise that a significant thickness of unrelated sediment underlies Mt. Ararat. Nor is there evidence for subsequent deposition of dissimilar sediments atop the debris flow material; the sandstone-bearing facies is only apparently overlain by a few $\mathrm{cm}$ of weathering residuum, sporadic calcium carbonate deposits, and occasional breakdown blocks, all of proximal origin. In other words, we may assume that most of the volume of sediment in Noah's Way between the breakdown pile at the south end and the junction at the north end is related to the Mt Ararat event. This assumption means that our volume estimates will be maximum-limiting because there is little direct constraint on depth to bedrock in Noah's Way.

We isolated features of interest in plan view and measured their volume using the 2.5D Volume tool in CloudCompare (2020), using a grid size of $1 \mathrm{~m}$. Volume is computed as the sum of gridded thicknesses above a reference level, here set to the inferred level of the bedrock passage floor. We measured the volume of Noah's Way enclosed by its ceiling, extending from the base of the breakdown pile in the south end, north to the junction area with Big Avenue, to be $6700 \mathrm{~m}^{3}$, of which $\sim 1700 \mathrm{~m}^{3}$ is in the junction area. Measured in the same way, the present volume of the Mt Ararat deposit is $\sim 3400 \mathrm{~m}^{3}$. If we assume that the original deposit filled the width of the passage, the volume of material eroded along the east (right lateral) margin has been $\sim 400 \mathrm{~m}^{3}$. In summary, our best maximum-limiting estimate for the original deposited volume is $3800 \mathrm{~m}^{3}$, or about $50 \%$ filling of the available passage space in Noah's Way (c.f. Fig 3).

\section{DISCUSSION}

The Mt. Ararat deposit in Mammoth Cave consists of poorly-sorted, matrix-supported, angular grains sourced from the Big Clifty sandstone and ranging from clay-sized through boulders of about $1 \mathrm{~m}$ in diameter, as quantified by detailed analysis of an exposed cross-section of the deposit. With over $60 \%$ of this material having grain sizes greater than $10 \mathrm{~cm}$ in diameter (Fig. 6), a volume between $2280 \mathrm{~m}^{3}$ and $4020 \mathrm{~m}^{3}$ of sandstone must have been directly sourced from the Big Clifty Sandstone Member. These sedimentological results support our interpretation of Mt. Ararat as a debris flow deposit originating from a mass-wasting or flood-like event in Doyle Valley, although the specific nature of the event occurring on the surface remains unclear. A conservative interpretation is that it represents a period of flash 
flooding in the Doyle Valley watershed that mobilized sandstone colluvium and temporarily accessed a now-obscured entrance to Noah's Way.

Further analysis provides estimates on flow velocities that would be needed to transport these grains as bedload either initially from the surface or later when eroding material away from the deposit. To estimate a high-end water speed for grains transported as bedload with water as the only fluid, we performed a calculation balancing the forces on an individual grain at the moment of incipient transport (Allen, 1985),

$$
\tau_{c r}=\frac{2 D(\alpha-\rho) g}{3 \cos \beta} \tan (\alpha-\beta)=\rho u_{*}^{2},
$$

where $\tau_{c r}$ is the critical shear stress at the threshold of entrainment $\left(\mathrm{N} \mathrm{m}^{-2}\right), D$ is the diameter of the grain size to be transported, $\sigma$ is the density of that grain (in this case, $\left.2650 \mathrm{~kg} \mathrm{~m}^{-3}\right), \rho$ is the density of the fluid $\left(1000 \mathrm{~kg} \mathrm{~m}^{-3}\right), g$ is the acceleration due to gravity $\left(9.8 \mathrm{~m} \mathrm{~s}^{-2}\right), \alpha$ is the angle between a line normal to the streambed and a line from the center of the grain to a grain-to-grain contact, $\beta$ is the angle of inclination of the streambed, $\rho u_{*}^{2}$ is the definition of shear stress, and $u_{*}$ is the shear velocity.

This calculation was performed for the median grain size of $0.2 \mathrm{~m}$ and the largest of $1 \mathrm{~m}$. To further simplify, we assumed that each transported grain was in contact with grains of identical dimensions and was transported by water. Fluids in debris flows can have a range of higher densities than water that would then result in a lower We then used a streambed slope of 0.05 ( $2.5 \mathrm{~m} / 50 \mathrm{~m}$; Fig. 8$)$ to calculate a shear velocity needed to entrain each of these grains. The resulting estimated average streamflow velocities were determined from the shear velocities,

$$
u=\frac{u_{*}}{\kappa} \ln \left(\frac{z}{z_{0}}\right)
$$

where $\kappa, 0.40$, is the von Karman constant (Bailey, et al., 2014), and $z / z_{0}$ is the roughness factor, which has been found to be about 9 for rough cave floors and walls through simulation of cave flow conditions (Bird et al., 2009). The calculated average velocities were $5.43 \mathrm{~m} \mathrm{~s}^{-1}$ for $0.2 \mathrm{~m}$ diameter cobbles and $12.15 \mathrm{~m} \mathrm{~s}^{-1}$ for $1 \mathrm{~m}$ diameter boulders.

Besides sediment grain size, other flow indicators in Noah's Way and Big Avenue include $1 \mathrm{~cm}$ to $2 \mathrm{~cm}$ scallops sculpted into limestone walls. Although geochronological tools do not currently exist to date the formation of scallops and it is not possible to determine when they developed in relation to the deposition of Mt. Ararat, they do represent flow conditions at some point in the period when these passages were hydrologically active. Palmer (2007) used these scallop lengths and the experimentally-derived relationship of Curl (1974) to estimate mean water speeds in this passage of about $1.25 \mathrm{~m} \mathrm{~s}^{-1}$ to $2.5 \mathrm{~m} \mathrm{~s}^{-1}$. The flows calculated using these two approaches are on the same order of magnitude and correlated well with the estimated velocities provided by Van Gundy and White (2009) of 5-9 m s${ }^{-1}$. They thus provide an estimate of the paleoflow conditions present in Noah's Way. These calculations assume particle motion in water, so velocities are likely higher than would be needed for transport of these grain sizes in a debris flow.

We may use a similar calculation to evaluate whether the scallop-based estimate of flow velocity would be a strong enough flow to result in the partial erosion observed as a channel along the eastern flank of Mt. Ararat. Entering our slowest estimated flow velocity into Equations (1) and (2), a stream flow of $1.25 \mathrm{~m} \mathrm{~s}^{-1}$ in Noah's Way would be sufficient to entrain material with a median grain size of $5 \mathrm{~mm}$, which is larger than that of the fine-grained matrix of Mt. Ararat.

To interpret the depositional conditions for Mt. Ararat, we referred to studies by Takahashi (1981), Pierson (1986), Hungr (1995), and Prior et al. (1984), which independently presented the simplest case of debris flow deposits resulting from single-flow events (Fig. 1). The physics behind channelized subsurface debris flows in karst conduits with a free upper surface, such as those leading to Mt. Ararat, was assumed to be similar to that of channelized surface debris flows. Assuming the simplest case, Mt. Ararat could have been deposited by a single debris flow event. This single event could have either (a) filled the entire passage of Noah's Way or (b) produced one large debris flow deposit with a classic single debris flow deposit profile (Fig. 1). A third possible scenario is that (c) two debris flows occurred, either as two surges resulting from the same event on the surface or as two flows from two discrete surface events.

Considering the possibility of event (a), had the Noah's Way passage at one time been completely full with sediment and then three-quarters of that been removed, we would expect to see residual staining on the ceiling and walls of the passage. Since the ceiling and upper walls are very cleanly exposed limestone, it is likely that this passage was never completely filled with siliciclastic sediments.

Scenario (b) would require a unique set of erosional events to sculpt a single debris flow into the basis for the modern profile of Mt. Ararat (Fig. 8A). Specifically, when we examined the morphology and grain-size distribution surrounding the secondary peak, it seemed unlikely that this shape was produced by erosion of a single debris-flow deposit. The shape of this peak is rounded, like that of the large peak and like that in the generalized sketch (Fig. 1). That peak also contains the second greatest concentration of coarse grains in Mt. Ararat. Immediately downstream of the second peak, grain sizes are fine (silts and sands) and then begin to coarsen again in the downstream direction. 
This evidence favors scenario (c). Having two heads of classic debris-flow deposit morphology, the smaller of the two superposed on the tail of the larger flow, this deposit appears likely to have resulted from multiple flow events (Fig. $8 \mathrm{~A})$. More data would be needed to determine whether these two depositional events were triggered by two surges from the same surface event or by two different surface events and to deduce how closely timed these events were. Considering paleoflow indicators, sedimentological evidence, and the morphology of Mt. Ararat, we conclude that the sedimentation chronology included two depositional events and two erosional events (Fig. 9):

1. Deposition of the large, 75-meter long, primary debris flow.

2. Fluvial erosion of the right-lateral side as evidenced by the channel cutting through the large flow. We were unable to conclude from field evidence as to whether it also affected the smaller overlying one. If it also eroded the second deposit, this would be event 3 .

3. Second debris flow deposition covering about 25 meters of upstream end of primary flow. If this deposit has been eroded by the stream, then this deposition would have been event 2 .

4. Fluvial erosion into a side passage at location $50 \mathrm{~m}$ into Noah's Way from the junction at Big Avenue. This eroded material from both the first and second deposits, resulting in a clean exposure of the entire debris flow cross-section.

Future numerical modeling studies could use the results of this study to evaluate the hydraulic conditions that resulted in Mt. Ararat. Further detailed field investigation of Doyle Valley and the downstream reaches of Big Avenue could provide further evidence for paleo topography on the surface above the cave and the overall sedimentation history of Mammoth Cave. Geochronology studies in the sinkholes of Doyle Valley and the sediments in and near Mt. Ararat could strengthen the chronology of sedimentation events in the region. Finally, future investigations may want to extend these findings and techniques as they apply to other debris flows in Mammoth Cave and in other caves.

\section{CONCLUSIONS}

In this work, we have provided a detailed characterization of the deposit named Mt. Ararat in Mammoth Cave. The combination of sedimentological, geophysical, and digital imaging data presented in this work supported the interpretation of the Mt. Ararat deposit as resulting from debris flow event(s) and enabled the calculations of the current volume of this deposit at approximately $3400 \mathrm{~m}^{3}$. Stratigraphic relationships with established Mammoth Cave system chronologies placed the age of the deposit at younger than 1.2 Ma. The evidence in this work supports the hypothesis of sandstone-floored-pond collapse(s) or valley-wall landslide(s) that initiated two debris flow surges into a now-obscured sinkhole entrance in the paleo Doyle Valley floor releasing a total more than $3800 \mathrm{~m}^{3}$ of material into the cave system. The sediment was deposited taking the form of Mt. Ararat with most of the material coming to rest at the junction of Noah's Way and Big Avenue, and a secondary volume of material coming to rest on top of the tail of the first debris flow. Material was partially eroded from the eastern side via a north-flowing stream either after or between the two deposition events, and later down a steep side passage. The findings of this work will inform further studies of karst-related erosional events, sediment transport, and deposition at different scales in karst aquifers as well as the ways in which surface and subsurface processes interact to contribute to karst landscape evolution.

\section{ACKNOWLEDGEMENTS}

Research in Mammoth Cave National Park was conducted under research permit \# MACA-2017-SCI-0020. This paper is dedicated to Colleen Olson of the Mammoth Cave Guide Force, a guiding light and inspiration to so many. Much gratitude goes out to Mary and Chuck Schubert, John Andersland, Tate Jones, JoAnn Jones, Christopher Chiros, Abby Kelly, Matt Covington, Missy Eppes, Chris Sheehan, Sam Berberich, Diana Garza, Reza Soltanian, Reza Ershadnia, Mark Passerby, Charles Fox, Karen Willmes, Bob Osburn, Karen Bird, Zach Bosch-Bird, Tyler Bosch-Bird, Samuel Bosch-Bird, and two anonymous reviewers who contributed useful insights. Additional thanks to the University of Cincinnati, Department of Geology, Siemens Digital Industries Software, Mammoth Cave National Park, the National Park Service, the Cave Research Foundation, and the University of Cincinnati 1819 Innovation Hub Groundfloor Makerspace. This work would not have been possible without the motivation and encouragement of Art and Peg Palmer, and Roger Brucker.

\section{REFERENCES}

Abrams, G., Bello, S.M., Di Modica, K., Pirson, S., and Bonjean, D., 2014, When Neanderthals used cave bear (Ursus spelaeus) remains: Bone retouchers from Unit 5 of Scladina Cave (Belgium): Quaternary International, v. 326, p. 274-287. https://doi.org/10.1016/j.quaint.2013.10.022.

Allen, J.R.L., 1985, Principles of Physical Sedimentology: London, George Allen \& Unwin, 272 p. https://doi.org/10.1007/978-1-4613-2545-1.

Bailey, S.C.C., Vallikivi, M., Hultmark, M., and Smits, A.J., 2014, Estimating the value of von Kárman's constant in turbulent pipe flow: Journal of Fluid Mechanics, v. 749, p. 79-98.

Bird, A.J., Springer, G.S., Bosch, R.F., and Curl, R.L., 2009, Effects of surface morphologies on flow behavior in karst conduits, Proceedings of the 15th International Congress of Speleology, p. 1417-1421. 
Bobachev, C., 2002, IPI2Win: A Windows Software for an Automatic Interpretation of Resistivity Sounding Data [Ph.D. Dissertation]: Moscow, Moscow State University, 320 p.

Bosch, R.F., and White, W.B., 2004, Lithofacies and transport of clastic sediments in karstic aquifers: in Studies of Cave Sediments: Springer, p. $1-22$.

Bosch, R.F., and White, W.B., 2018, Lithofacies and transport for clastic sediments in karst conduits: in Karst Groundwater Contamination and Public Health: Springer, p. 277-281. https://doi.org/10.1007/978-3-319-51070-5_32.

Burger, H.R., Sheehan, A.F., and Jones, C.H., 2006, Introduction to Applied Geophysics: Exploring the Shallow Subsurface: New York, WW Norton, $554 \mathrm{p}$.

Cave Research Foundation, CRF Field Survey Book 526, 1971, Used with written permission of Cave Research Foundation and National Park Service.

Cave Research Foundation, CRF Field Survey Book 4489, 2010a, Used with written permission of Cave Research Foundation and National Park Service.

Cave Research Foundation, CRF Field Survey Book 4495, 2010b, Used with written permission of Cave Research Foundation and National Park Service.

Cave Research Foundation, CRF Field Survey Book 4607, 2012, Used with written permission of Cave Research Foundation and National Park Service.

Chess, D.L., Chess, C.A., Sasowsky, I.D., Schmidt, V.A., and White, W.B., 2010, Clastic sediments in the Butler Cave-Sinking Creek System, Virginia, USA: Acta Carsologica, v. 39, no. 1, p. 11-26. https://doi.org/10.3986/ac.v39i1.109.

CloudCompare (version 2.10.1), 2020, https://cloudcompare.org/.

Curl, R.L., 1974, Deducing flow velocity in cave conduits from scallops: The National Speleological Society Bulletin, v. 36, no. 2, p. 1-5.

Dirks, P.H.G.M., Kibii, J.M., Kuhn, B.F., Steininger, C., Churchill, S.E., Kramers, J.D., and Pickering, R., 2010, Geological setting and age of Australopithecus sediba from Southern Africa: Science, v. 328, no. 5975, p. 205-208. https://doi.org/10.1126/science.1184950.

Gilbertson, D., Bird, M., Hunt, C., McLaren, S., Banda, R.M., Pyatt, B., Rose, J., and Stephens, M., 2005, Past human activity and geomorphological change in a guano-rich tropical cave mouth: Initial Interpretations of the Late Quaternary Succession in the Great Cave of Niah, Sarawak: Asian Perspectives, p. 16-41. https://doi.org/10.1353/asi.2005.0007.

Gillieson, D., 1986, Cave sedimentation in the New Guinea Highlands: Earth Surface Processes and Landforms, v.11, no. 5, p. 533-543.

GPS Kit (version 8.0.4), 2017, GPS Kit - Offline GPS Tracker: The original GPS app, iOS, Gafara, LLC, https://apps.apple.com/us/app/gps-kitoffline-gps-tracker/id287909017.

Granger, D.E., Fabel, D., and Palmer, A.N., 2001, Pliocene- Pleistocene incision of the Green River, Kentucky, determined from radioactive decay of Cosmogenic $26 \mathrm{Al}$ and 10Be in Mammoth Cave dediments: Geological Society of America Bulletin, v. 113, no. 7, p. 825-836. https://doi. org/10.1130/0016-7606(2001)113<0825:PPIOTG>2.0.CO;2.

Gustavsson, M., Kolstrup, E., and Seijmonsbergen, A.C., 2006, A new symbol-and-GIS based detailed geomorphological mapping system: Renewal of a scientific discipline for understanding landscape development: Geomorphology, v. 77, no. 1-2, p. 90-111.

Haynes, D.D., 1964, Geology of the Mammoth Cave Quadrangle, Kentucky: USGS, https://pubs.er.usgs.gov/publication/gq351, [accessed May 21, 2019].

Hungr, O., 1995, A model for the runout analysis of rapid flow slides, debris lows, and avalanches: Canadian Geotechnical Journal, v. 32, no. 4, p. 610-623.

Jurgiel, B., Verchere, P., Tourigny, E., and Becerra, J., 2020, Profile Tool, https://plugins.qgis.org/plugins/profiletool/.

Kellerhals, R., Shaw, J., and Arora, V.K., 1975, On grain size from thin sections: The Journal of Geology, v. 83, no. 1, p. 79-96. https://www.jstor. org/stable/30062340?seq=1\#metadata_info_tab_contents.

Mussett, A.E. and Khan, M.A., 2000, Looking into the Earth: an introduction to geological geophysics: Cambridge University Press, 470 p.

Ortiz, L.W., Ettinger, H.J., Fairchild, C.I., 1975, Calibration standards for counting asbestos: American Industrial Hygiene Association Journal, v. 36, no. 2, p. 104-112.

Palmer, A.N., 1989, Geomorphic history of the Mammoth Cave System, in Karst Hydrology: Springer, p. 317-337.

Palmer, A.N., 2007, Cave Geology: Dayton, Cave Books, 454 p.

Palmer, A.N., Olson, R., and Palmer, M.V., 2019, Evidence for extreme floods in New Discovery and related passages in Mammoth Cave: Cave Research Foundation Newsletter, v. 47, no. 2, p. 3-6.

Palmer, A.N., and Palmer, M.V., 2005, Hydraulic processes in the origin of Tiankengs: Cave and Karst Science, v. 32, no. 2/3, p. 101-106.

Pierson, T. C. 1986. Flow behavior of channelized debris flows, Mount St. Helens, Washington. In Hillslope Processes, Abrahams AD (ed.). Allen and Unwin: Boston; $269 \pm 296$.

Pierson, T. C., 1986, Flow behavior of channelized debris flows, Mount St. Helens, Washington: in Hillslope Processes, Abrahams A.D. (ed.). Allen and Unwin: Boston; p. 269-296.

Prior, D.B., Bornhold, B.D., and Johns, M.W., 1984, Depositional characteristics of a submarine debris flow: The Journal of Geology, v. 92, no. 6 , p. 707-727.

QGIS.org, 2020, QGIS Geographic Information System. OpenSource Geospatial Foundation Project. https://qgis.org.

Santamaría, D., Fortea, J., De la Rasilla, M., Martinez, L., Martinez, E., Cañaveras, J.C., and Sánchez-Moral, S., 2010, The Technological and typological behaviour of a Neanderthal group from El Sidrón Cave (Asturias, Spain): Oxford Journal of Archaeology, v. 29, no. 2, p. 119-148. https://doi.org/10.1111/j.1468-0092.2010.00342.x.

Siemens, 2020, Modeling Geometry in Simcenter STAR-CCM+ Documentation [accessed July 22, 2020], https://documentation.thesteveportal. plm.automation.siemens.com/starccmplus_latest_en/index.html?param=7vl4S\&authLoc=https://thesteveportal.plm.automation.siemens.com/ AuthoriseRedirect\#page/STARCCMP\%2FGUIID-B18CC064-4DDB-4610-ADED-81B92767FF41.html\%23wwconnect_header

Smith, T., ed., 2014, Manual on test sieving methods / prepared by ASTM Committee E29 as Guidelines for establishing sieve analysis procedures: West Conshohocken, PA, ASTM manual series MNL32, 71 p. https://www.astm.org/mnl32-5th-eb.html.

Studinski, J.M., and Grubbs, S.A., 2007, Environmental factors affecting the distribution of aquatic invertebrates in temporary ponds in Mammoth Cave National Park, Kentucky, USA.: Hydrobiologia, v. 575, no. 1, p. 211-220.

Takahashi, T., 1981, Debris Flow: Annual Review of Fluid Mechanics, v. 13, no. 1, p. 57-77.

USGS, 1972, Mammoth Cave National Park and Vicinity: United States Geological Survey, https://store.usgs.gov/assets/MOD/StoreFiles/DenverPDFs/24K/KY/60861_KY_Mammoth_Cave_NP_and_Vicinity.pdf. [accessed May 17, 2019]. 
Bosch, Ward, Bird, Sturmer, and Olson

USNPS, 2018, Mammoth Cave National Park map, https://www.nps.gov/maca/planyourvisit/maps.htm. [accessed September 23, 2020].

Van Gundy, J.J., and White, W.B., 2009, Sediment flushing in Mystic Cave, West Virginia, USA, in response to the 1985 Potomac Valley Flood: International Journal of Speleology, v. 38, no. 2, p. 103-109. https://doi.org/10.5038/1827-806x.38.2.2.

Wilcox, J., 1971, New Discovery, Mammoth Cave, Mammoth Cave National Park, Kentucky: Cave Research Foundation, 1 sheet. 